\title{
MADRASAH
}

Jurnal Pendidikan dan Pembelajaran Dasar

p ISSN: 1979-5599 | e ISSN: 2502-194X

P a g e

\section{PERILAKU SISWA SEKOLAH DASAR DALAM MENYELESAIKAN SOAL CERITA MATEMATIKA}

\author{
Ria Norfika Yuliandari \\ Universitas Islam Negeri (UIN) Maulana Malik Ibrahim Malang, Indonesia \\ Fikachu_math@pgmi.uin-malang.ac.id
}

\begin{abstract}
Learning word problem can be used as a means to drill students to solve problems. In word problem, students are demanded to be able to comprehend problems contexts that are given, make Math model from those problems, find ways to solve them and re-examine the results gotten. While in fact, it is shown that there are still a lot of students who find difficulties so that they make some errors in solving word problems. Related to the wills that appear to know the students' behaviour and errors that are done by students while solving word problem by using Polya solving problem model. This study is focused to identify and classify errors that are done by students in solving word problems.. In addition, the reasons why the errors occur and hoe to solve them are going to be revealed here. This study uses qualitative descriptive approach. This research is done by students of fifth graders in SDN 1 Kebonsari Malang. The subjects of this study are chosen through the entrance test with errors variations and discussion results with teachers. There are eight students that are chosen who are divided into two students who have high ability, two students who have medium ability and four students who have low ability. Behaviour, types of errors and the reasons are gotten from the result of test and interview. The behaviour that is shown by the students of fifth graders in SDN 1 Kebonsari Malang are classified into four categories such as DTA-not proficient and DTA-proficient. Moreover, it is also found that there are other different reasons occur, but they are still related to the Pape behaviour problem solving, that is DTA-Limited Context + behaviour translation but without explanation, DTA Proficient + behaviour translation and DTA-Not Proficient + behavior translation. Based on the result of the study, it is suggested that teachers should know the errors that are often done by the students before the lesson begins to emphasize the teaching and learning process in those errors. Teachers are also able to give some practices, mainly in word problem to drill students' experiment in solving them. Furthermore, the steps of solving the problems by using Polya model need to emphasize in terms of its usage so that it can practice students' thinking process systematically. For the further research, if other researchers want to use this model to conduct further research so that they need to consider the application of this method in students and schools' condition that are relatively different or other Math topics in the same subject.
\end{abstract}

Keyword: Behaviour; Math Word Problem; Polya model

Copyright (C) 2016 Madrasah Jurnal Pendidikan dan Pembelajaran Dasar. All Right Reserved

\section{A. PENDAhuluaN}

Pada akhir dekade 80-an terjadi perubahan paradigma dalam pembelajaran matematika yang digagas oleh National Council of Teacher of Mathemathics Standards for School Mathematics (NCTM), dimana pemecahan masalah dan penalaran menjadi salah satu fokus

Vol. 9 No. 1, Desember 2016

Madrasah homepage: http://ejournal.uin-malang.ac.id/index.php/madrasah/index 
utama dalam program pembelajaran matematika sekolah termasuk sekolah dasar. Perubahan ini karena pembelajaran selama ini yang dilakukan adalah konvensional. Pembelajaran konvensional yang selama ini diterapkan oleh guru hanya terbatas pada kegiatan ceramah, tanya jawab dan pemberian tugas (Sa'dijah, 2000). Perubahan paradigma tersebut kemudian diadaptasi dalam kurikulum di Indonesia terutama mulai Kurikulum 2004 (KBK) dan Kurikulum 2006 (KTSP). Dalam Kurikulum Berbasis Kompetensi disebutkan bahwa pemecahan masalah merupakan fokus dalam pembelajaran matematika (Depdiknas, 2002:8). Penguasaan setiap standart kompetensi selalu dilengkapi dengan suatu kompetensi dasar pemecahan masalah yang berkaitan dengan standart kompotensi tersebut.

Salah satu bentuk permasalahan yang sesuai dengan pendekatan pemecahan masalah adalah soal cerita. Dalam menyelesaikan soal cerita, siswa dituntut untuk dapat memahami soal, membuat model matematika dari permasalahan tersebut, menemukan cara penyelesaiannya dan menafsirkan kembali selesaian yang diperoleh. Muser dan Burger (2008:ix) menyatakan bahwa masalah matematika biasanya dinyatakan dalam bentuk soal cerita, baik tertulis atau verbal. Ini sesuai dengan pendapat Sutawidjaja (1991:47) yaitu bahwa masalah dalam matematika dapat berbentuk soal cerita. Soal cerita lebih sulit dipecahkan oleh siswa daripada soal-soal yang melibatkan bilangan-bilangan. Soal yang melibatkan bilangan-bilangan sudah dikerjakan secara rutin oleh siswa. Namun pada kenyataannya menunjukkan bahwa masih banyak yang merasa kesulitan sehingga membuat kesalahan dalam menyelesaikan masalah dalam bentuk soal cerita, terutama pada jenjang Sekolah Dasar.

Pada umumnya, untuk tingkat Sekolah Dasar, soal cerita yang merupakan pendekatan pemecahan masalah diberikan masih pada level sederhana dalam pengerjaannya. Kesulitan yang biasa muncul diduga karena sulit memahami soal dan bagaimana prosedur penyelesaiannya. Karena kesulitan ini maka banyak terjadi kesalahan dalam menyelesaikan soal cerita. Seperti yang ditemukan oleh Suharjo (2005) yaitu beberapa SD di Kota Malang menunjukkan bahwa murid-murid SD dikelas rendah mempunyai kesulitan dalam mengerjakan soal cerita. Manalu (1996:1) juga mengungkapkan pengalaman sejumlah guru matematika Sekolah Dasar di Indonesia yang menyatakan bahwa topik matematika yang disajikan dalam bentuk soal cerita pada umumnya dirasakan masih sulit bagi siswa, dan banyak pula guru yang merasa sulit mengajarkannya sehingga guru dan siswa tidak menyenangi soal cerita. Beberapa penelitian pembelajaran matematika yang telah dilaksanakan melaporkan adanya kesulitan yang dialami siswa dalam menyelesaikan soal bentuk cerita (Haji, 1994; Suarjana, 1997; Akhmad, 2000). Pada umumnya dilaporkan bahwa faktor kesulitan yang dialami siswa adalah lemahnya kemampuan siswa dalam memahami isi soal yang disajikan dalam bentuk soal cerita. Rudnistky, Etheradge, Freeman, \& Gilbert (1995:467) juga menunjukkan bahwa soal bentuk cerita masih sulit bagi siswa. Faktor kesulitannya terletak pada struktur matematika dan bahasa. Kennedy, Eliot dan Krulee yang diungkapkan oleh Hudojo (1990:187) melaporkan bahwa soal yang berhubungan dengan bilangan tidak begitu menyulitkan siswa SD, tetapi soal-soal yang menggunakan kalimat sangat menyulitkan bagi siswa yang berkemampuan kurang.

Prinsip pemecahan masalah yang popular dan sering digunakan oleh penelitipeneliti di Indonesia adalah model Polya. Dengan tahapan Polya, dapat digunakan untuk mengetahui perilaku dan letak kesalahan yang dilakukan siswa pada saat menyelesaikan soal cerita karena Polya mempunyai empat tahapan yang dapat dijadikan sebagai alat untuk menginvestigasi kemampuan siswa saat menyelesaikan soal cerita. Ini karena

Vol. 9 No. 1, Desember 2016

Madrasah homepage: http://ejournal.uin-malang.ac.id/index.php/madrasah/index 


\section{MADRASAH}

Jurnal Pendidikan dan Pembelajaran Dasar

p ISSN: 1979-5599 | e ISSN: 2502-194X

P a g e

George Polya (2008) dalam bukunya "How to Solve It" mengemukakan empat langkah yang dapat dilakukan untuk memecahkan masalah yang dinamakan pemecahan masalah model Polya, yakni: Understand the problem (memahami masalah), Devise a plan (merencanakan pemecahan), Carry out the plan (melaksanakan rencana), Look back (melihat kembali)

Pemecahan masalah model Polya ini mempunyai empat tahapan dimana setiap tahapan sangat terperinci dan jelas. Pada tahap pertama understand problem (memahami masalah) diawali dengan membaca soal, menentukan atau mengidentifikasi apa (data) yang diketahui, apa yang ditanyakan (tidak diketahui), syarat-syarat apa yang diperlukan, apa syarat-syarat bisa dipenuhi, memeriksa apakah syarat-syarat yang diketahui mencukupi untuk mencari yang tidak diketahui, dan menyatakan kembali masalah asli dalam bentuk yang lebih operasional (dapat dipecahkan). Pada tahap kedua, devise a plan (merencanakan penyelesaian) yang dilakukan adalah memeriksa apakah sudah pernah melihat sebelumnya atau melihat masalah yang sama dalam bentuk yang berbeda, mengaitkan dengan teorema yang mungkin berguna, memperhatikan yang tidak diketahui dari soal dan mencoba mencari hubungan antara informasi yang diberikan dengan yang tidak diketahui yang memungkinkan menemukan cara bagaimana menghitungnya. Tahapan ketiga yaitu carry out the plan (melaksanakan rencana penyelesaian) yaitu melaksanakan rencana penyelesaian yang tertuang pada tahap kedua, menuliskan langkah-langkah penyelesaian, mengecek kebenaran setiap langkah dan membuktikan bahwa setiap langkah benar. Tahapan yang terakhir adalah look back (melihat kembali), yaitu meneliti kembali hasil yang telah diperoleh, mengecek hasilnya, mengecek argumennya.

Dengan menggunakan pemecahan masalah model Polya di atas, diharapkan dapat mengetahui perilaku yang dilakukan oleh siswa SDN I Kebonsari Malang saat menyelesaikan soal cerita.

\section{B. METODE PENELITIAN}

Rancangan penelitian yang digunakan dalam penelitian ini adalah penelitian kualitatif deskriptif. Hal ini karena data yang akan dikumpulkan dalam penelitian ini adalah deskripsi tentang bagaimana perilaku siswa dalam menyelesaikan soal cerita pada materi bilangan bulat.

Penelitian dilakukan pada siswa kelas V SDN Kebonsari I Malang yang beralamat di Jl. Satsuitubun 178 Kebonsari Sukun Malang. Subyek penelitian adalah delapan siswa siswi yang terdiri dari dua siswa berkemampuan tinggi, dua siswa berkemampuan sedang dan empat siswa berkemampuan rendah.

Teknik pengumpulan data yang digunakan pada penelitian ini adalah teknik tes awal, tes soal, wawancara dan rekaman. Tes awal digunakan sebagai salah satu dasar dalam memilih subyek penelitian. Tes soal digunakan untuk mengetahui perilaku dan letak kesalahan siswa dalam menyelesaikan soal cerita. Wawancara digunakan untuk menggali informasi secara lebih detail dan obyektif tentang perilaku dan letak kesalahan siswa serta sebab-sebab terjadinya kesalahan dalam mengerjakan soal cerita. Rekaman digunakan untuk menghindari hilangnya atau terlewatnya informasi selama berlangsungnya wawancara, maka percakapan penulis dengan siswa direkam menggunakan alat rekam.

Setelah data terkumpul, maka selanjutnya data dianalisis. Teknik analisis data hasil tes awal, hasil tes soal cerita, wawancara dan rekaman akan mengacu kepada pendapat

Vol. 9 No. 1, Desember 2016

Madrasah homepage: http://ejournal.uin-malang.ac.id/index.php/madrasah/index 
Miles dan Huberman (1992:16) yang menyatakan analisis data meliputi tiga hal yakni (1) mereduksi data kegiatan menyeleksi, (2) penyajian data, (3) penarikan kesimpulan dan verifikasi.

\section{HASIL PENELITIAN}

Hasil pengumpulan dan analisis data pada penelitian ini secara garis besar dikemukan sebagai berikut.

Tabel C.1 Perilaku yang Ditunjukkan S1 Saat Menyelesaikan Soal Cerita

\begin{tabular}{|c|c|c|}
\hline \multirow{2}{*}{$\begin{array}{l}\text { No } \\
\text { Item }\end{array}$} & \multicolumn{2}{|c|}{ Perilaku penyelesaian soal } \\
\hline & Soal tes I & $\begin{array}{l}\text { Soal tes II } \\
\end{array}$ \\
\hline $\mathrm{I}$ & $\begin{array}{l}\text { a. Mampu membaca soal dengan } \\
\text { jelas dan menceritakan kembali } \\
\text { maksud dari soal dengan kalimat } \\
\text { sendiri. } \\
\text { b. Menemukan informasi dan } \\
\text { menuliskannya. } \\
\text { c. Tidak mampu menentukan } \\
\text { rencana penyelesaian dan } \\
\text { melakukan perhitungan } \\
\text { matematis. } \\
\text { d. Tidak menggunakan konteks } \\
\text { dalam perhitunganya. } \\
\text { e. Menuliskan jawaban akhir } \\
\text { dengan pernyataan verbal. } \\
\text { f. Tidak ada penjelasan alasan pada } \\
\text { setiap langkah perhitungannya. }\end{array}$ & $\begin{array}{l}\text { a. Mampu membaca soal dengan } \\
\text { jelas dan menceritakan kembali } \\
\text { maksud dari soal dengan kalimat } \\
\text { sendiri. } \\
\text { b. Menemukan informasi dan } \\
\text { menuliskannya. } \\
\text { c. Mampu menentukan rencana } \\
\text { penyelesaian dan melakukan } \\
\text { perhitungan matematis. } \\
\text { d. Tidak menggunakan konteks } \\
\text { masalah dalam perhitungan. } \\
\text { e. Menuliskan jawaban akhir } \\
\text { dengan pernyataan verbal. } \\
\text { f. Tidak ada penjelasan alasan pada } \\
\text { langkah penyelesaiannya. }\end{array}$ \\
\hline II & $\begin{array}{l}\text { a. Mampu membaca soal dengan } \\
\text { jelas dan menceritakan kembali isi } \\
\text { soal dengan kalimat sendiri. } \\
\text { b. Menemukan informasi dan } \\
\text { menuliskannya. } \\
\text { c. Tidak mampu menentukan cara } \\
\text { penyelesaian tetapi mampu } \\
\text { melakukan perhitungan } \\
\text { matematis. } \\
\text { d. Tidak menggunakan konteks } \\
\text { masalah dalam perhitungan. } \\
\text { e. Menuliskan jawaban akhir } \\
\text { dengan pernyataan verbal. } \\
\text { f. Tidak ada penjelasan alasan pada } \\
\text { setiap langkahnya. }\end{array}$ & $\begin{array}{l}\text { a. Mampu membaca soal dengan } \\
\text { jelas dan menceritakan kembali } \\
\text { maksud soal dengan kalimat } \\
\text { sendiri. } \\
\text { b. Menemukan informasi dan } \\
\text { menuliskannya. } \\
\text { c. Menentukan rencana } \\
\text { penyelesaian dan mampu } \\
\text { melakukan perhitungan } \\
\text { matematis. } \\
\text { d. Tidak menggunakan konteks } \\
\text { masalah dalam perhitungan. } \\
\text { e. Menuliskan jawaban akhir } \\
\text { dengan pernyataan verbal. } \\
\text { f. Tidak ada penjelasan alasan pada } \\
\text { setiap langkahnya. }\end{array}$ \\
\hline III & $\begin{array}{l}\text { a. Mampu membaca soal dengan } \\
\text { jelas dan menceritakan kembali } \\
\text { maksud soal dengan kalimat } \\
\text { sendiri. }\end{array}$ & $\begin{array}{l}\text { a. Mampu membaca soal dengan } \\
\text { jelas dan menceritakan kembali } \\
\text { maksud soal dengan kalimat } \\
\text { sendiri. }\end{array}$ \\
\hline
\end{tabular}

Vol. 9 No. 1, Desember 2016

Madrasah homepage: http://ejournal.uin-malang.ac.id/index.php/madrasah/index 


\section{MADRASAH}

Jurnal Pendidikan dan Pembelajaran Dasar

p ISSN: 1979-5599 | e ISSN: 2502-194X

P a g e

\begin{tabular}{|c|c|c|}
\hline \multirow{2}{*}{$\begin{array}{l}\text { No } \\
\text { Item }\end{array}$} & \multicolumn{2}{|c|}{ Perilaku penyelesaian soal } \\
\hline & Soal tes I & Soal tes II \\
\hline & $\begin{array}{l}\text { b. Menemukan informasi dan } \\
\text { menuliskannya. } \\
\text { c. Tidak dapat menentukan rencana } \\
\text { penyelesaian tetapi mampu } \\
\text { melakukan perhitungan } \\
\text { matematis. } \\
\text { d. Tidak menggunakan konteks } \\
\text { masalah dalam perhitungannya. } \\
\text { e. Menuliskan jawaban akhir } \\
\text { dengan pernyataan verbal. } \\
\text { f. Tidak ada penjelasan alasan pada } \\
\text { setiap langkah penyelesaiannya. }\end{array}$ & $\begin{array}{l}\text { b. Menemukan informasi tetapi } \\
\text { tidak menuliskannya dengan } \\
\text { lengkap. } \\
\text { c. Tidak dapat menentukan rencana } \\
\text { penyelesaian tetapi mampu } \\
\text { melakukan perhitungan } \\
\text { matematis. } \\
\text { d. Tidak menggunakan konteks } \\
\text { masalah dalam perhitungan. } \\
\text { e. Menuliskan jawaban akhir } \\
\text { dengan pernyataan verbal. } \\
\text { f. Tidak ada penjelasan alasan pada } \\
\text { setiap langkah penyelesaiannya. }\end{array}$ \\
\hline
\end{tabular}

Tabel C.2 Perilaku yang Ditunjukkan S2 Saat Menyelesaikan Soal Cerita

\begin{tabular}{|c|c|c|}
\hline \multirow{2}{*}{$\begin{array}{l}\text { No } \\
\text { Item }\end{array}$} & \multicolumn{2}{|c|}{ Perilaku penyelesaian soal } \\
\hline & Soal tes I & Soal tes II \\
\hline \multirow[t]{6}{*}{ I } & $\begin{array}{l}\text { a. Mampu membaca soal dengan } \\
\text { jelas dan menceritakan kembali } \\
\text { maksud dari soal dengan kalimat } \\
\text { sendiri. }\end{array}$ & $\begin{array}{l}\text { a. Mampu membaca soal dengan } \\
\text { jelas dan menceritakan kembali } \\
\text { maksud dari soal dengan kalimat } \\
\text { sendiri. }\end{array}$ \\
\hline & $\begin{array}{l}\text { b. Menemukan informasi dan } \\
\text { menuliskannya. }\end{array}$ & $\begin{array}{l}\text { b. Menemukan informasi dan } \\
\text { menuliskannya. }\end{array}$ \\
\hline & $\begin{array}{l}\text { c. Dapat menentukan rencana } \\
\text { penyelesaian tetapi tidak mampu }\end{array}$ & $\begin{array}{l}\text { c. Mampu menentukan rencana } \\
\text { penyelesaian dan melakukan }\end{array}$ \\
\hline & $\begin{array}{l}\text { melakukan } \quad \text { perhitungan } \\
\text { matematis. }\end{array}$ & $\begin{array}{l}\text { perhitungan matematis. } \\
\text { d. Tidak menggunakan konteks }\end{array}$ \\
\hline & $\begin{array}{l}\text { d. Menggunakan konteks masalah } \\
\text { dalam perhitungan namun } \\
\text { terbatas. }\end{array}$ & $\begin{array}{l}\text { masalah dalam perhitungannya. } \\
\text { e. Menuliskan jawaban akhir secara } \\
\text { verbal. }\end{array}$ \\
\hline & $\begin{array}{l}\text { e. Menuliskan jawaban akhir } \\
\text { dengan pernyataan verbal. } \\
\text { f. Tidak ada penjelasan alasan pada } \\
\text { setiap langkah perhitungannya. }\end{array}$ & $\begin{array}{l}\text { f. Tidak ada penjelasan alasan pada } \\
\text { langkah penyelesaiannya. }\end{array}$ \\
\hline
\end{tabular}

Vol. 9 No. 1, Desember 2016

Madrasah homepage: http://ejournal.uin-malang.ac.id/index.php/madrasah/index 


\begin{tabular}{|c|c|c|}
\hline \multirow{2}{*}{$\begin{array}{l}\text { No } \\
\text { Item }\end{array}$} & \multicolumn{2}{|c|}{ Perilaku penyelesaian soal } \\
\hline & Soal tes I & Soal tes II \\
\hline II & $\begin{array}{l}\text { a. Mampu membaca soal dengan } \\
\text { jelas dan menceritakan maksud } \\
\text { soal dengan kalimat sendiri. } \\
\text { b. Menemukan informasi dan } \\
\text { menuliskannya. } \\
\text { c. Menentukan cara penyelesaian } \\
\text { dan dapat melakukan } \\
\text { perhitungan } \\
\text { d. Tidak menggunakan konteks } \\
\text { masalah dalam perhitungan. } \\
\text { e. Konteks masalah pada penulisan } \\
\text { jawaban akhir terbatas. } \\
\text { f. Tidak ada penjelasan alasan pada } \\
\text { setiap langkahnya. }\end{array}$ & $\begin{array}{l}\text { a. Mampu membaca soal dengan } \\
\text { jelas dan bisa menceritakan } \\
\text { kembali maksud soal dengan } \\
\text { kalimat sendiri. } \\
\text { b. Menemukan informasi dan } \\
\text { menuliskannya. } \\
\text { c. Mampu menentukan rencana } \\
\text { penyelesaian dan melakukan } \\
\text { perhitungan matematis. } \\
\text { d. Tidak menggunakan konteks } \\
\text { masalah dalam perhitungan. } \\
\text { e. Menuliskan jawaban akhir } \\
\text { dengan pernyataan verbal } \\
\text { f. Tidak ada penjelasan alasan pada } \\
\text { setiap langkah penyelesaiannya. }\end{array}$ \\
\hline III & $\begin{array}{l}\text { a. Mampu membaca soal dengan } \\
\text { jelas dan menceritakan kembali } \\
\text { maksud soal dengan kalimat } \\
\text { sendiri. } \\
\text { b. Menemukan informasi dan } \\
\text { menuliskannya. } \\
\text { c. Mampu menentukan rencana } \\
\text { penyelesaian dan melakukan } \\
\text { perhitungan matematis. } \\
\text { d. Tidak menggunakan konteks } \\
\text { masalah dalam perhitungan. } \\
\text { e. Menuliskan jawaban akhir } \\
\text { dengan pernyataan verbal. } \\
\text { f. Ada penjelasan alasan pada satu } \\
\text { langkah penyelesaiannya. }\end{array}$ & $\begin{array}{l}\text { a. Mampu membaca soal dengan } \\
\text { jelas dan menceritakan kembali } \\
\text { maksud soal dengan kalimat } \\
\text { sendiri. } \\
\text { b. Menemukan informasi dan } \\
\text { menuliskannya. } \\
\text { c. Tidak mampu menentukan } \\
\text { rencana penyelesaian melakukan } \\
\text { perhitungan matematis. } \\
\text { d. Tidak menggunakan konteks } \\
\text { dalam perhitungan. } \\
\text { e. Jawaban akhir menggunakan } \\
\text { pernyataan vebal. } \\
\text { f. Tidak ada penjelasan alasan pada } \\
\text { setiap langkahnya. }\end{array}$ \\
\hline
\end{tabular}

Vol. 9 No. 1, Desember 2016

Madrasah homepage: http://ejournal.uin-malang.ac.id/index.php/madrasah/index 


\section{MADRASAH}

Jurnal Pendidikan dan Pembelajaran Dasar

p ISSN: 1979-5599 | e ISSN: 2502-194X

P a g e

63

Tabel C.3 Perilaku yang Ditunjukkan S3 Saat Menyelesaikan Soal Cerita

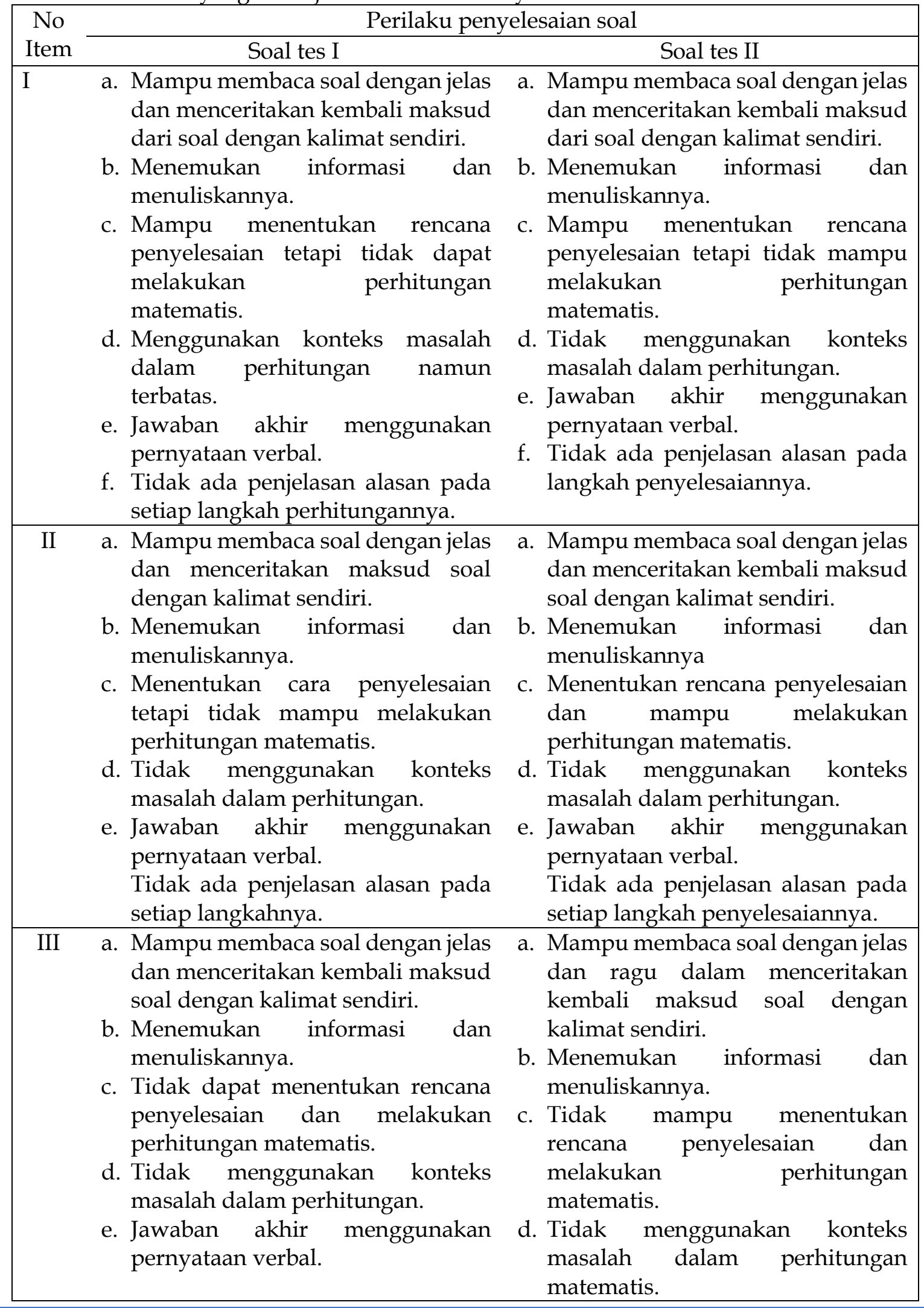

Vol. 9 No. 1, Desember 2016

Madrasah homepage: http://ejournal.uin-malang.ac.id/index.php/madrasah/index 


\begin{tabular}{|ccc|}
\hline No & \multicolumn{2}{c|}{ Perilaku penyelesaian soal } \\
\cline { 2 - 4 } Item & \multicolumn{1}{c|}{ Soal tes I } & \multicolumn{1}{c|}{ Soal tes II } \\
\hline \multirow{2}{*}{ f. } & Tidak ada penjelasan alasan pada & e. Jawaban akhir menggunakan \\
& setiap langkah penyelesaiannya. & pernyataan verbal. \\
& & f. $\begin{array}{l}\text { Tidak ada penjelasan alasan pada } \\
\text { setiap langkah penyelesaiannya. }\end{array}$ \\
\hline
\end{tabular}

Tabel C.4 Perilaku yang Ditunjukkan S4 Saat Menyelesaikan Soal Cerita

\begin{tabular}{|c|c|c|}
\hline \multirow{2}{*}{$\begin{array}{l}\text { No } \\
\text { Item }\end{array}$} & \multicolumn{2}{|c|}{ Perilaku penyelesaian soal } \\
\hline & Soal tes I & Soal tes II \\
\hline I & $\begin{array}{l}\text { a. Mampu membaca soal dengan jelas } \\
\text { dan menceritakan kembali maksud } \\
\text { dari soal dengan kalimat sendiri. } \\
\text { b. Menemukan informasi dan } \\
\text { menuliskannya. } \\
\text { c. Mampu menentukan rencana } \\
\text { penyelesaian tetapi tidak mampu } \\
\text { melakukan perhitungan } \\
\text { matematis. } \\
\text { d. Menggunakan konteks masalah } \\
\text { dalam perhitungan namun } \\
\text { terbatas. } \\
\text { e. Jawaban akhir menggunakan } \\
\text { pernyataan verbal. } \\
\text { f. Tidak ada penjelasan alasan pada } \\
\text { setiap langkah perhitungannya. }\end{array}$ & $\begin{array}{l}\text { a. Mampu membaca soal dengan jelas } \\
\text { dan menceritakan kembali maksud } \\
\text { dari soal dengan kalimat sendiri. } \\
\text { b. Menemukan informasi namun } \\
\text { tidak menuliskannya dengan } \\
\text { lengkap. } \\
\text { c. Mampu menentukan rencana } \\
\text { penyelesaian dan melakukan } \\
\text { perhitungan matematis. } \\
\text { d. Tidak menggunakan konteks } \\
\text { masalah dalam perhitungan. } \\
\text { e. Jawaban akhir mengunakan } \\
\text { pernyataan verbal. } \\
\text { f. Tidak ada penjelasan alasan pada } \\
\text { langkah penyelesaiannya. }\end{array}$ \\
\hline II & $\begin{array}{l}\text { a. Mampu membaca soal dengan jelas } \\
\text { dan menceritakan kembali maksud } \\
\text { soal dengan kalimat sendiri. } \\
\text { b. Menemukan informasi dan } \\
\text { menuliskannya. } \\
\text { c. Tidak dapat menentukan cara } \\
\text { penyelesaian dan melakukan } \\
\text { perhitungan matematis. } \\
\text { d. Menggunakan konteks masalah } \\
\text { dalam perhitungan namun } \\
\text { terbatas. } \\
\text { e. Jawaban akhir menggunakan } \\
\text { pernyataan verbal. } \\
\text { f. Tidak ada penjelasan alasan pada } \\
\text { setiap langkahnya. }\end{array}$ & $\begin{array}{l}\text { a. Mampu membaca soal dengan jelas } \\
\text { dan menceritakan kembali maksud } \\
\text { soal dengan kalimat sendiri. } \\
\text { b. Menemukan informasi dan } \\
\text { menuliskannya. } \\
\text { c. Menentukan rencana penyelesaian } \\
\text { dan mampu melakukan } \\
\text { perhitungan matematis. } \\
\text { d. Tidak menggunakan konteks } \\
\text { masalah dalam perhitungan. } \\
\text { e. Jawaban akhir menggunakan } \\
\text { pernyataan verbal. } \\
\text { f. Tidak ada penjelasan alasan pada } \\
\text { setiap langkah penyelesaiannya. }\end{array}$ \\
\hline III & $\begin{array}{l}\text { a. Mampu membaca soal dengan } \\
\text { jelas dan menceritakan kembali } \\
\text { maksud soal dengan kalimat } \\
\text { sendiri. } \\
\text { b. Menemukan informasi dan } \\
\text { menuliskannya. }\end{array}$ & $\begin{array}{l}\text { a. Mampu membaca soal dengan } \\
\text { jelas tetapi ragu pada saat } \\
\text { menceritakan kembali maksud } \\
\text { soal dengan kalimat sendiri. } \\
\text { b. Menemukan informasi tetapi tidak } \\
\text { menuliskan dengan lengkap. }\end{array}$ \\
\hline
\end{tabular}

Vol. 9 No. 1, Desember 2016

Madrasah homepage: http://ejournal.uin-malang.ac.id/index.php/madrasah/index 


\section{MADRASAH}

Jurnal Pendidikan dan Pembelajaran Dasar

p ISSN: 1979-5599 | e ISSN: 2502-194X

P a g e

\begin{tabular}{|c|c|c|}
\hline \multirow{2}{*}{$\begin{array}{l}\text { No } \\
\text { Item }\end{array}$} & \multicolumn{2}{|c|}{ Perilaku penyelesaian soal } \\
\hline & Soal tes I & Soal tes II \\
\hline & $\begin{array}{l}\text { c. Menentukan rencana penyelesaian } \\
\text { dan mampu melakukan } \\
\text { perhitungan matematis. } \\
\text { d. Tidak menggunakan konteks } \\
\text { masalah dalam perhitungan. } \\
\text { e. Jawaban akhir menggunakan } \\
\text { penyataan verbal. } \\
\text { f. Tidak ada penjelasan alasan pada } \\
\text { setiap langkah penyelesaiannya. }\end{array}$ & $\begin{array}{l}\text { c. } \text { Tidak mampu menentukan } \\
\text { rencana penyelesaian dan } \\
\text { melakukan perhitungan } \\
\text { matematis. } \\
\text { d. Tidak menggunakan konteks } \\
\text { masalah dalam perhitungan. } \\
\text { e. Jawaban akhir menggunakan } \\
\text { pernyataan verbal. } \\
\text { f. Tidak ada penjelasan alasan pada } \\
\text { setiap langkah penyelesaiannya. }\end{array}$ \\
\hline
\end{tabular}

Tabel C.5 Perilaku yang Ditunjukkan S5 Saat Menyelesaikan Soal Cerita

\begin{tabular}{|c|c|c|}
\hline No & Perilaku pen & elesaian soal \\
\hline Item & Soal tes I & Soal tes II \\
\hline $\mathrm{I}$ & $\begin{array}{l}\text { a. Mampu membaca soal dengan jelas } \\
\text { dan menceritakan kembali maksud } \\
\text { dari soal dengan kalimat sendiri. } \\
\text { b. Menemukan informasi dan } \\
\text { menuliskannya. } \\
\text { c. Tidak mampu menentukan } \\
\text { rencana penyelesaian dan } \\
\text { perhitungan matematis. } \\
\text { d. Menggunakan konteks masalah } \\
\text { dalam perhitungan namun } \\
\text { terbatas. } \\
\text { e. Jawaban akhir menggunakan } \\
\text { pernyataan verbal. } \\
\text { f. Tidak ada penjelasan alasan pada } \\
\text { setiap langkah perhitungannya. }\end{array}$ & $\begin{array}{l}\text { a. Mampu membaca soal dengan jelas } \\
\text { dan menceritakan kembali maksud } \\
\text { dari soal dengan kalimat sendiri. } \\
\text { b. Menemukan informasi dan } \\
\text { menuliskannya. } \\
\text { c. Mampu menentukan rencana } \\
\text { penyelesaian dan melakukan } \\
\text { perhitungan matematis. } \\
\text { d. Tidak menggunakan konteks } \\
\text { masalah dalam perhitungan. } \\
\text { e. Jawaban akhir menggunakan } \\
\text { pernyataan verbal. } \\
\text { f. Tidak ada penjelasan alasan pada } \\
\text { langkah } \\
\text { penyelesaiannya. }\end{array}$ \\
\hline II & $\begin{array}{l}\text { a. Mampu membaca soal dengan jelas } \\
\text { dan menceritakan kembali isi soal } \\
\text { dengan kalimat sendiri. } \\
\text { b. Menemukan informasi dan } \\
\text { menuliskannya. } \\
\text { c. Mampu menentukan cara } \\
\text { penyelesaian dan melakukan } \\
\text { perhitungan matematis. } \\
\text { d. Menggunakan konteks masalah } \\
\text { dalam perhitungan namun } \\
\text { terbatas. } \\
\text { e. Jawaban akhir menggunakan } \\
\text { pernyataan verbal. }\end{array}$ & $\begin{array}{l}\text { a. Mampu membaca soal dengan jelas } \\
\text { dan menceritakan kembali maksud } \\
\text { soal dengan kalimat sendiri. } \\
\text { b. Menemukan informasi dan } \\
\text { menuliskannya. } \\
\text { c. Mampu menentukan rencana } \\
\text { penyelesaian dan melakukan } \\
\text { perhitungan matematis } \\
\text { d. Tidak menggunakan konteks } \\
\text { dalam perhitungan. } \\
\text { e. Jawaban akhir menggunakan } \\
\text { pernyataan verbal. } \\
\text { f. Tidak ada penjelasan alasan pada } \\
\text { setiap langkah penyelesaiannya. }\end{array}$ \\
\hline
\end{tabular}

Vol. 9 No. 1, Desember 2016

Madrasah homepage: http://ejournal.uin-malang.ac.id/index.php/madrasah/index 


\begin{tabular}{|c|c|c|}
\hline \multirow{2}{*}{$\begin{array}{l}\text { No } \\
\text { Item } \\
\end{array}$} & \multicolumn{2}{|c|}{ Perilaku penyelesaian soal } \\
\hline & Soal tes I & Soal tes II \\
\hline & $\begin{array}{l}\text { f. Tidak ada penjelasan alasan pada } \\
\text { setiap langkahnya. }\end{array}$ & \\
\hline III & $\begin{array}{l}\text { a. Mampu membaca soal dengan jelas } \\
\text { dan menceritakan kembali maksud } \\
\text { soal dengan kalimat sendiri. } \\
\text { b. Menemukan informasi dan } \\
\text { menuliskannya. } \\
\text { c. Tidak mampu menentukan } \\
\text { rencana penyelesaian dan } \\
\text { melakukan perhitungan. } \\
\text { d. Tidak menggunakan konteks } \\
\text { dalam perhitungan. } \\
\text { e. Jawaban akhir menggunakan } \\
\text { pernyataan verbal. } \\
\text { f. Tidak ada penjelasan alasan pada } \\
\text { setiap langkah penyelesaiannya. }\end{array}$ & $\begin{array}{l}\text { a. Mampu membaca soal dengan jelas } \\
\text { tetapi ragu saat menceritakan } \\
\text { kembali maksud soal dengan } \\
\text { kalimat sendiri. } \\
\text { b. Menemukan informasi tetapi tidak } \\
\text { menuliskannya. } \\
\text { c. Tidak mampu menentukan } \\
\text { rencana penyelesaian dan } \\
\text { melakukan perhitungan. } \\
\text { d. Tidak menggunakan konteks } \\
\text { dalam perhitungan. } \\
\text { e. Jawaban akhir menggunakan } \\
\text { pernyataan verbal. } \\
\text { f. Perhitungan tidak ada kaitannya } \\
\text { dengan masalah. } \\
\text { g. Tidak ada penjelasan alasan pada } \\
\text { setiap langkah penyelesaiannya. }\end{array}$ \\
\hline
\end{tabular}

Tabel C.6 Perilaku yang Ditunjukkan S6 Saat Menyelesaikan Soal Cerita

\begin{tabular}{|c|c|c|}
\hline \multirow{2}{*}{$\begin{array}{c}\text { No } \\
\text { Item }\end{array}$} & \multicolumn{2}{|c|}{ Perilaku penyelesaian soal } \\
\hline & Soal tes I & Soal tes II \\
\hline $\mathrm{I}$ & $\begin{array}{l}\text { a. Mampu membaca soal dengan jelas } \\
\text { dan menceritakan kembali maksud } \\
\text { dari soal dengan kalimat sendiri. } \\
\text { b. Mampu menemukan informasi dan } \\
\text { menuliskannya. } \\
\text { c. Menentukan rencana penyelesaian } \\
\text { tetapi tidak mampu melakukan } \\
\text { perhitungan matematis. } \\
\text { d. Menggunakan konteks dalam } \\
\text { perhitungan namun } \\
\text { terbatas. } \\
\text { e. Jawaban akhir menggunakan } \\
\text { pernyataan verbal. } \\
\text { f. Tidak ada penjelasan alasan pada } \\
\text { setiap langkah perhitungannya. }\end{array}$ & $\begin{array}{l}\text { a. Mampu membaca soal dengan } \\
\text { jelas dan menceritakan kembali } \\
\text { maksud dari soal dengan kalimat } \\
\text { sendiri. } \\
\text { b. Dapat menemukan informasi } \\
\text { dan menuliskannya. } \\
\text { c. Menentukan rencana } \\
\text { penyelesaian tetapi tidak mampu } \\
\text { melakukan perhitungan. } \\
\text { d. Tidak menggunakan konteks } \\
\text { dalam perhitungan. } \\
\text { e. Jawaban akhir menggunakan } \\
\text { pernyataa verbal. } \\
\text { f. Tidak ada penjelasan alasan pada } \\
\text { langkah penyelesaiannya. }\end{array}$ \\
\hline II & $\begin{array}{l}\text { a. Mampu membaca soal dengan jelas } \\
\text { dan menceritakan kembali maksud } \\
\text { soal dengan kalimat sendiri. } \\
\text { b. Mampu menemukan informasi dan } \\
\text { menuliskannya. }\end{array}$ & $\begin{array}{l}\text { a. Mampu membaca soal dengan } \\
\text { jelas dan menceritakan kembali } \\
\text { maksud soal dengan kalimat } \\
\text { sendiri. } \\
\text { b. Menemukan informasi dan } \\
\text { menuliskannya. }\end{array}$ \\
\hline
\end{tabular}

Vol. 9 No. 1, Desember 2016

Madrasah homepage: http://ejournal.uin-malang.ac.id/index.php/madrasah/index 


\section{MADRASAH}

Jurnal Pendidikan dan Pembelajaran Dasar

p ISSN: 1979-5599 | e ISSN: 2502-194X

P a g e

\begin{tabular}{|c|c|c|}
\hline \multirow{2}{*}{$\begin{array}{l}\text { No } \\
\text { Item }\end{array}$} & \multicolumn{2}{|c|}{ Perilaku penyelesaian soal } \\
\hline & Soal tes I & Soal tes II \\
\hline & $\begin{array}{l}\text { c. Tidak dapat menentukan cara } \\
\text { penyelesaian dan melakukan } \\
\text { perhitungan matematis. } \\
\text { d. Menggunakan konteks dalam } \\
\text { perhitungan namun terbatas. } \\
\text { e. Jawaban akhir pernyataan verbal. } \\
\text { f. Tidak ada penjelasan alasan pada } \\
\text { setiap langkahnya. }\end{array}$ & $\begin{array}{l}\text { c. Tidak menentukan rencana } \\
\text { penyelesaian dan melakukan } \\
\text { perhitungan matematis. } \\
\text { d. Tidak menggunakan konteks } \\
\text { dalam perhitungan. } \\
\text { e. Jawaban akhir menggunakan } \\
\text { pernyataan verbal. } \\
\text { f. Tidak ada penjelasan alasan pada } \\
\text { setiap langkah penyelesaiannya. }\end{array}$ \\
\hline III & $\begin{array}{l}\text { a. Mampu membaca soal dengan jelas } \\
\text { dan menceritakan kembali maksud } \\
\text { soal dengan kalimat sendiri. } \\
\text { b. Menemukan informasi dan } \\
\text { menuliskannya. } \\
\text { c. Menentukan rencana penyelesaian } \\
\text { tetapi tidak mampu melakukan } \\
\text { perhitungan matematis. } \\
\text { d. Tidak menggunakan konteks dalam } \\
\text { perhitungan. } \\
\text { e. Tidak menuliskan jawaban akhir. } \\
\text { f. Tidak ada penjelasan alasan pada } \\
\text { setiap langkah penyelesaiannya. }\end{array}$ & $\begin{array}{l}\text { a. Mampu membaca soal dengan } \\
\text { jelas. } \\
\text { b. Ragu saat menceritakan kembali } \\
\text { maksud soal dengan kalimat } \\
\text { sendiri. } \\
\text { c. Menemukan informasi dan } \\
\text { menuliskannya. } \\
\text { d. Tidak menentukan rencana } \\
\text { penyelesaian dan melakukan } \\
\text { perhitungan matematis. } \\
\text { e. Tidak menggunakan konteks } \\
\text { dalam masalah. } \\
\text { f. Perhitungan tidak ada kaitannya } \\
\text { dengan masalah. } \\
\text { g. Jawaban akhir menggunakan } \\
\text { pernyataan verbal. } \\
\text { h. Tidak ada penjelasan alasan pada } \\
\text { setiap langkahnya. }\end{array}$ \\
\hline
\end{tabular}

Tabel C.7 Perilaku yang Ditunjukkan S7 Saat Menyelesaikan Soal Cerita

\begin{tabular}{|c|c|c|}
\hline No & Perilaku peny & lesaian soal \\
\hline Item & Soal tes I & Soal tes II \\
\hline I & $\begin{array}{l}\text { a. Mampu membaca soal dengan jelas } \\
\text { tetapi ragu saat menceritakan } \\
\text { kembali maksud dari soal dengan } \\
\text { kalimat sendiri }\end{array}$ & $\begin{array}{l}\text { a. Mampu membaca soal dengan } \\
\text { jelas dan menceritakan kembali } \\
\text { maksud dari soal dengan kalimat } \\
\text { sendiri }\end{array}$ \\
\hline & $\begin{array}{l}\text { b. Tidak mampu menuliskan informasi } \\
\text { dari soal dengan lengkap. }\end{array}$ & $\begin{array}{l}\text { b. Tidak dapat menuliskan informasi } \\
\text { secara lengkap. }\end{array}$ \\
\hline & $\begin{array}{l}\text { c. Mampu menentukan rencana } \\
\text { penyelesaian tetapi tidak mampu } \\
\text { melakukan perhitungan matematis. }\end{array}$ & $\begin{array}{l}\text { c. Mampu menentukan rencana } \\
\text { penyelesaian tetapi tidak mampu } \\
\text { melakukan perhitungan. }\end{array}$ \\
\hline & $\begin{array}{l}\text { d. Menggunakan konteks masalah } \\
\text { dalam perhitungan namun terbatas. }\end{array}$ & $\begin{array}{l}\text { d. Tidak menggunakan } \\
\text { dalam perhitungan. }\end{array}$ \\
\hline
\end{tabular}

Vol. 9 No. 1, Desember 2016

Madrasah homepage: http://ejournal.uin-malang.ac.id/index.php/madrasah/index 


\begin{tabular}{|c|c|c|}
\hline \multirow{3}{*}{$\begin{array}{l}\text { No } \\
\text { Item }\end{array}$} & \multicolumn{2}{|c|}{ Perilaku penyelesaian soal } \\
\hline & Soal tes I & Soal tes II \\
\hline & $\begin{array}{l}\text { e. Jawaban akhir menggunakan } \\
\text { pernyataan verbal. } \\
\text { f. Tidak ada penjelasan alasan pada } \\
\text { setiap langkah perhitungannya. }\end{array}$ & $\begin{array}{l}\text { e. Jawaban akhir menggunakan } \\
\text { pernyataan verbal. } \\
\text { f. Tidak ada penjelasan alasan pada } \\
\text { langkah penyelesaiannya. }\end{array}$ \\
\hline II & $\begin{array}{l}\text { a. Mampu membaca soal dengan jelas } \\
\text { tetapi ragu saat menceritakan } \\
\text { kembali isi soal dengan kalimat } \\
\text { sendiri. } \\
\text { b. Tidak mampu menuliskan informasi } \\
\text { secara lengkap. } \\
\text { c. Tidak dapat menentukan cara } \\
\text { penyelesaian tetapi mampu dalam } \\
\text { melakukan perhitungan matematis. } \\
\text { d. Tidak menggunakan konteks dalam } \\
\text { perhitungan. } \\
\text { e. Jawaban akhir menggunakan } \\
\text { pernyataan verbal. } \\
\text { f. Tidak ada penjelasan alasan pada } \\
\text { setiap langkahnya. }\end{array}$ & $\begin{array}{l}\text { a. Mampu membaca soal dengan } \\
\text { jelas tetapi ragu menceritakan } \\
\text { kembali maksud soal dengan } \\
\text { kalimat sendiri. } \\
\text { b. Tidak mampu menuliskan } \\
\text { informasi secara lengkap. } \\
\text { c. Tidak mampu menentukan } \\
\text { rencana penyelesaian dan } \\
\text { melakukan perhitungan } \\
\text { matematis. } \\
\text { d. Perhitungan tidak ada kaitannya } \\
\text { dengan masalah. } \\
\text { e. Jawaban akhir menggunakan } \\
\text { pernyataan verbal. } \\
\text { f. Tidak ada penjelasan alasan pada } \\
\text { setiap langkah penyelesaiannya. }\end{array}$ \\
\hline III & $\begin{array}{l}\text { a. Mampu membaca soal dengan jelas. } \\
\text { b. Tidak dapat menceritakan kembali } \\
\text { maksud soal dengan kalimat sendiri. } \\
\text { c. Tidak dapat menuliskan informasi } \\
\text { secara lengkap. } \\
\text { d. Dapat menentukan rencana } \\
\text { penyelesaian tetapi tidak mampu } \\
\text { melakukan perhitungan matematis. } \\
\text { e. Tidak menggunakan konteks } \\
\text { masalah dalam perhitungan. } \\
\text { f. Jawaban akhir menggunakan } \\
\text { pernyataan verbal. } \\
\text { g. Tidak ada penjelasan alasan pada } \\
\text { setiap langkah penyelesaiannya. }\end{array}$ & $\begin{array}{l}\text { a. Mampu membaca soal dengan } \\
\text { jelas. } \\
\text { b. Tidak dapat menceritakan kembali } \\
\text { maksud soal dengan kalimat } \\
\text { sendiri. } \\
\text { c. Tidak dapat menuliskan informasi } \\
\text { secara lengkap. } \\
\text { d. Tidak menentukan rencana } \\
\text { penyelesaian dan melakukan } \\
\text { perhitungan matematis. } \\
\text { e. Tidak menggunakan konteks } \\
\text { dalam perhitungan. } \\
\text { f. Jawaban akhir menggunakan } \\
\text { pernyataan verbal } \\
\text { g. Tidak ada penjelasan alasan pada } \\
\text { setiap langkah penyelesaiannya. }\end{array}$ \\
\hline
\end{tabular}

Tabel C.8 Perilaku yang Ditunjukkan S8 Saat Menyelesaikan Soal Cerita

\begin{tabular}{|c|c|c|}
\hline No & \multicolumn{2}{|c|}{ Perilaku penyelesaian soal } \\
\hline Item & Soal tes I & Soal tes II \\
\hline I & $\begin{array}{l}\text { a. Mampu membaca soal dengan jelas } \\
\text { dan menceritakan kembali maksud } \\
\text { dari soal dengan kalimat sendiri. } \\
\text { b. Menemukan informasi dan } \\
\text { menuliskannya. }\end{array}$ & $\begin{array}{l}\text { a. Mampu membaca soal dengan } \\
\text { jelas dan menceritakan kembali } \\
\text { maksud dari soal dengan kalimat } \\
\text { sendiri. }\end{array}$ \\
\hline
\end{tabular}

Vol. 9 No. 1, Desember 2016

Madrasah homepage: http://ejournal.uin-malang.ac.id/index.php/madrasah/index 


\section{MADRASAH}

Jurnal Pendidikan dan Pembelajaran Dasar

p ISSN: 1979-5599 | e ISSN: 2502-194X

P a g e

69

\begin{tabular}{|c|c|c|}
\hline \multirow{3}{*}{$\begin{array}{l}\text { No } \\
\text { Item }\end{array}$} & \multicolumn{2}{|c|}{ Perilaku penyelesaian soal } \\
\hline & Soal tes I & Soal tes II \\
\hline & $\begin{array}{l}\text { c. Mampu menentukan rencana } \\
\text { penyelesaian tetapi tidak mampu } \\
\text { melakukan perhitungan matematis. } \\
\text { d. Mengunakan konteks masalah dalam } \\
\text { perhitungan namun terbatas. } \\
\text { e. Jawaban akhir menggunakan } \\
\text { pernyataan verbal. } \\
\text { f. Tidak ada penjelasan alasan pada } \\
\text { setiap langkah perhitungannya. }\end{array}$ & $\begin{array}{l}\text { b. Menemukan informasi dan } \\
\text { menuliskannya. } \\
\text { c. Mampu menentukan rencana } \\
\text { penyelesaian dan melakukan } \\
\text { perhitungan matematis. } \\
\text { d. Tidak menggunakan konteks } \\
\text { masalah dalam perhitungan. } \\
\text { e. Jawaban akhir menggunakan } \\
\text { pernyataan verbal. } \\
\text { f. Tidak ada penjelasan alasan pada } \\
\text { langkah penyelesaiannya. }\end{array}$ \\
\hline II & $\begin{array}{l}\text { a. Mampu membaca soal dengan jelas } \\
\text { dan menceritakan kembali maksud } \\
\text { dari soal dengan kalimat sendiri. } \\
\text { b. Menemukan informasi dan } \\
\text { menuliskannya. } \\
\text { c. Menentukan cara penyelesaian dan } \\
\text { mampu melakukan perhitungan } \\
\text { matematis. } \\
\text { d. Menggunakan konteks masalah } \\
\text { dalam perhitungan namun terbatas. } \\
\text { e. Jawaban akhir menggunakan } \\
\text { pernyataan verbal. } \\
\text { f. Tidak ada penjelasan alasan pada } \\
\text { setiap langkahnya. }\end{array}$ & $\begin{array}{l}\text { a. Mampu membaca soal dengan } \\
\text { jelas. } \\
\text { b. Ragu menceritakan kembali } \\
\text { maksud soal dengan kalimat } \\
\text { sendiri. } \\
\text { c. Tidak menuliskan informasi secara } \\
\text { lengkap. } \\
\text { d. Tidak dapat menentukan rencana } \\
\text { penyelesaian dan melakukan } \\
\text { perhitungan matematis. } \\
\text { e. Tidak menggunakan konteks } \\
\text { masalah dalam perhitungan. } \\
\text { f. Perhitungan tidak ada kaitannya } \\
\text { dengan masalah. } \\
\text { g. Jawaban akhir menggunakan } \\
\text { pernyataan verbal. } \\
\text { h. Tidak ada penjelasan alasan pada } \\
\text { setiap langkah penyelesaiannya. }\end{array}$ \\
\hline III & $\begin{array}{l}\text { a. Mampu membaca soal dengan jelas. } \\
\text { b. Ragu menceritakan kembali maksud } \\
\text { soal dengan kalimat sendiri. } \\
\text { c. Menemukan informasi dan } \\
\text { menuliskannya. } \\
\text { d. Menentukan rencana penyelesaian. } \\
\text { e. Tidak mampu melakukan } \\
\text { perhitungan matematis. } \\
\text { f. Tidak menggunakan konteks } \\
\text { masalah dalam perhitungan. } \\
\text { g. Jawaban akhir menggunakan } \\
\text { pernyataan verbal. } \\
\text { h. Tidak ada penjelasan alasan pada } \\
\text { setiap langkah penyelesaiannya. }\end{array}$ & $\begin{array}{l}\text { a. Mampu membaca soal dengan } \\
\text { jelas. } \\
\text { b. Tidak dapat menceritakan kembali } \\
\text { maksud soal dengan kalimat } \\
\text { sendiri. } \\
\text { c. Tidak menuliskan informasi } \\
\text { dengan lengkap. } \\
\text { d. Tidak dapat menentukan rencana } \\
\text { penyelesaian dan melakukan } \\
\text { perhitungan matematis. } \\
\text { e. Tidak menggunakan konteks } \\
\text { masalah dalam perhitungan. } \\
\text { f. Jawaban akhir menggunakan } \\
\text { pernyataan verbal. }\end{array}$ \\
\hline
\end{tabular}

Vol. 9 No. 1, Desember 2016

Madrasah homepage: http://ejournal.uin-malang.ac.id/index.php/madrasah/index 


\begin{tabular}{|c|c|c|}
\hline No & \multicolumn{2}{|c|}{ Perilaku penyelesaian soal } \\
\hline Item & Soal tes I & Soal tes II \\
\hline & & $\begin{array}{l}\text { g. Tidak ada penjelasan alasan pada } \\
\text { setiap langkah penyelesaiannya. }\end{array}$ \\
\hline
\end{tabular}

\section{PEMBAHASAN}

Berdasarkan pada perilaku pemecahan masalah Pape, perilaku siswa saat menyelesaikan soal cerita yang ditemukan maka diketahui klasifikasi perilaku siswa saat menyelesaikan soal cerita adalah sebagai berikut.

1. DTA Proficient. Indikator siswa yang termasuk dalam kategori ini adalah sebagai berikut:
a. Menemukan informasi tetapi tidak dituliskan.
b. Secara langsung melakukan perhitungan matematis.
c. Tidak menggunakan konteks masalah dalam perhitungannya.
d. Mungkin menuliskan jawaban akhir berdasarkan konteks masalah.
e. Tidak membaca ulang.

2. DTA-Not Proficient. Indikator siswa yang termasuk dalam kategori ini adalah sebagai berikut:
a. Kurang dan kesulitan dalam memahami soal, menentukan solusi dan melakukan perhitungan.
b. Menemukan informasi tetapi tidak dituliskan.
c. Membaca ulang namun hanya perilaku saja.
d. Tidak menggunakan konteks masalah dalam perhitungannya.
e. Perhitungan yang dilakukan kurang makna dan tidak ada kaitannya dengan masalah.

3. DTA-Limited Context + behavior translation but without explanation. Indikator siswa yang termasuk dalam kategori ini adalah sebagai berikut:
a. Dapat menemukan informasi dan menuliskannya.
b. Menemukan cara solusi dan menuliskannya.
c. Menggunakan konteks masalah dalam perhitungannya namun terbatas.
d. Langsung melakukan perhitungan matematis.
e. Mungkin menuliskan jawaban dengan menggunakan konteks masalah
f. Tidak ada penjelasan pada perhitungan matematis.

4. DTA Proficient + behavior translation with limited context. Indikator siswa yang termasuk dalam kategori ini adalah sebagai berikut:
a. Menemukan informasi dan cara yang digunakan serta menuliskannya semuanya atau hanya salah satunya.
b. Secara langsung melakukan perhitungan matematis.
c. Mungkin menggunakan konteks masalah dalam perhitungannya.
d. Mungkin menuliskan jawaban akhir berdasarkan konteks masalah.
e. Tidak membaca ulang.

5. DTA-Not Proficient + behavior translation. Indikator siswa yang termasuk dalam kategori ini adalah sebagai berikut:
a. Kurang dan kesulitan melakukan perhitungan.
b. Menemukan informasi dan cara solusi tetapi menuliskannya.
c. Membaca ulang namun hanya perilaku saja.
d. Tidak menggunakan konteks masalah dalam perhitungannya.

Vol. 9 No. 1, Desember 2016

Madrasah homepage: http://ejournal.uin-malang.ac.id/index.php/madrasah/index 


\section{MADRASAH}

Jurnal Pendidikan dan Pembelajaran Dasar

p ISSN: 1979-5599 | e ISSN: 2502-194X

P a g e

e. Perhitungan yang dilakukan kurang makna dan tidak ada kaitannya dengan masalah.

\section{E. PENUTUP}

\section{Simpulan}

Bertolak dari hasil penelitian tersebut maka dapat dikemukan kesimpulan bahwa klasifikasi perilaku penyelesaian soal cerita yang ditunjukkan adalah sebagai berikut:

a. DTA Proficient

b. DTA-Not Proficient

c. DTA-Limited Context + behavior translation but without explanation

d. DTA Proficient + behavior translation with limited context

e. DTA-Not Proficient + behavior translation

\section{Saran}

Saran yang dapat disampaikan berdasarkan hasil penelitian, yaitu:

a. Perilaku penyelesaian soal cerita yang ditunjukkan oleh siswa pada penelitian ini masih cenderung ke perilaku DTA (Direct Translation Approach), oleh karena itu untuk mendapatkan perilaku penyelesaian soal cerita MBA (Meaning Based Approach) pada siswa maka yang harus dilakukan oleh guru adalah lebih banyak dan sering memberikan latihan-latihan soal cerita untuk melatih pengalaman dan kemampuan siswa dalam menyelesaikan soal cerita. kemampuan-kemampuan itu diantaranya adalah kemampuan translation, solution, interpretation dan chek.

b. Tahap-tahap penyelesaian masalah sebaiknya perlu ditekankan penggunaannya karena ini akan melatih siswa untuk berfikir secara sistematis.

c. Sebaiknya guru memberikan bimbingan dan petunjuk yang berupa pertanyaanpertanyaan sederhana untuk membantu siswa yang berkemampuan rendah untuk dapat memahami masalah.

d. Guru dapat menemukan atau menggunakan strategi pembelajaran yang tepat untuk dapat meningkatkan motivasi belajar siswa.

e. Penelitian ini hanya menganalisis perilaku yang dilakukan oleh siswa SDN I Kebonsari Malang dalam menyelesaikan soal cerita bilangan bulat. Siswa yang diambil untuk subyek penelitian terdiri dari 8 (delapan) siswa yang terdiri dari 2 siswa berkemampuan tinggi, 2 siswa berkemampuan sedang dan 4 siswa yang berkemampuan rendah. Oleh karena itu, jika ingin dilaksanakan penelitian lebih lanjut maka perlu dipertimbangkan penerapannya untuk kondisi siswa dan sekolah yang berbeda atau untuk topik matematika yang lain pada subyek yang sama.

\section{REFERENSI}

Akhmad, S. (2000). Membantu Mengatasi Ksesulitan Siswa dalam Menyelesaikan Soal Cerita Satu Langkah (One Step Word Problems) di Kelas II Sekolah Dasar Negeri Kauman I Kota Malang. Tesis tidak diterbitkan. Malang: PPS UM Malang. 
Depdiknas. (2002). Kurikulum Berbasis Kompetensi. Jakarta: Pusat Kurikulum, Balitbang Depdiknas.

Haji, S. (1994). Diagnosis Kesulitan Siswa dalam Menyelesaikan Soal Cerita di Kelas 5 SDN Percobaan. Tesis tidak diterbitkan. Malang: PPS IKIP Malang.

Hudojo, Herman. (1990). Strategi Mengajar Belajar Matematika. Malang: IKIP Malang.

Milles, M. B. \& Huberman, A, M. (1992). Analisis Data Kualitatif. Terjemahan oleh Rohidi, T. R. Jakarta: UI Press.

Musser, G.L. \& Burger, W.F. (2008). Mathematics for Elementary Teachers. A Contemporary Approach (Eight Edition). New York: McMillan Publishing Company, Inc.

Rudnitsky, A., Etheredge, S., Freeman, S.M., \& Gilbert, T. (1995). Learning to Solve Addition and Substraction Word Problems Through Structure Plus Writing Approach. Journal for research in Mathematics Education. 26(5) : 467-468.

Sa'dijah, C. (2000). pembelajaran Matematika Secara Konstruktivis Suatu Upaya Meningkatkan Kebermaknaan Pemahaman Matematika Bagi Siswa. Seminar Nasional Pengajaran Matematika Sekolah Menengah, Malang, 25 Maret 2000.

Suarjana, I. M. (1997). Remidiasi Kesulitan Siswa Kelas II Dalam Menyeledsaikan Soal Cerita di Sekolah Dasar Negerin Klojen I Kodya Malang. Tesis tidak diterbitkan. Malang:PPS IKIP Malang.

Sutawidjaja, A. (1991/1992). Pendidikan Matematika III (Modul Prajabatan D-2 PGSD). Jakarta: Dirjen. Dikti. 